\title{
GUCA2A Gene
}

National Cancer Institute

\section{Source}

National Cancer Institute. GUCA2A Gene. NCI Thesaurus. Code C126515.

This gene plays a role in the positive regulation of intestinal guanylate cyclase. 